\title{
New cell lines from Lymantria xylina (Lepidoptera: Lymantriidae): Characterization and susceptibility to baculoviruses
}

\author{
Chih-Yu Wu, Chung-Hsiung Wang * \\ Department of Entomology, National Taiwan University, Taipei, Taiwan, ROC \\ Received 27 April 2006; accepted 8 August 2006 \\ Available online 20 September 2006
}

\begin{abstract}
Four new cell lines, designated as NTU-LY-1 to -4, respectively, were established from the pupal tissues of Lymantria xylina Swinhoe (Lepidoptera: Lymantriidae). These cell lines have been cultured approximately 80 passages during 2 years in TNM-FH medium supplemented with $8 \%$ fetal bovine serum, at a constant temperature of $28^{\circ} \mathrm{C}$. Each line consists of three major morphological types: round cells, spindle-shaped cells, and giant cells. The characterization of these cell lines showed that they are different from previously established lines derived from related Lepidopteran species. All new lines were susceptible to the L. xylina multiple nucleopolyhedrovirus (LyxyMNPV) and appeared to have a good potential for studying this virus.
\end{abstract}

(C) 2006 Elsevier Inc. All rights reserved.

Keywords: Lymantria xylina; Cell line; RAPD-PCR; Isozyme; Nucleopolyhedrovirus

\section{Introduction}

Since Grace (1962) successfully established long-term cultures of insect cells, over 500 continuous cell lines have been established from over 100 insect species (Lynn, 1999). Insect cell lines have become more important as a tool for the production of insect pathogenic viruses and recombinant proteins by the use of the baculovirus expression vector as well as in studies on physiology and developmental biology (Granados and McKenna, 1995; Hink et al., 1991; Maeda et al., 1985; Smith et al., 1983; Wu et al., 1989; Vaughn, 1981). Virtually, every cell line is a potential or actual source of material for molecular biologists to use in a wide range of studies.

The casuarina moth, Lymantria xylina Swinehoe (Lepidoptera: Lymantriidae), is a forest pest in Taiwan, Japan, India, and on the eastern coast of mainland China (Chao et al., 1996; Matsumura, 1933; Xiao, 1992). Due to the extension of its host plant range and the increasing agricultural loss, this moth now becomes a significant quarantine

\footnotetext{
* Corresponding author. Fax: +8862 27364329.

E-mail address: wangch@ccms.ntu.edu.tw (C.-H. Wang).
}

pest (Chang and Weng, 1985; Chao et al., 1996). An epizootic disease, nucleopolyhedrosis, of L. xylina larvae occurs from spring to early summer in Taiwan and mainland China, and the key pathogen was found to be L. xylina multiple nucleopolyhedrovirus (LyxyMNPV) (Cheng et al., 1987; Liang et al., 1986; Wu and Wang, 2005; Yu et al., 1997). This virus appears to effectively suppress $L$. xylina population in field trials (Cheng et al., 1987) and is being investigated as a possible addition to the integrated pest management (IPM) programs against this moth.

Production of LyxyMNPV involved the large-scale rearing of L. xylina larvae. This process is labor intensive and several challenges need to be met (e.g. the conditions for breaking embryonic diapause and the development of artificial diets) to obtain a reliable source of the host insect. In vitro production of LyxyMNPV in a highly susceptible cell line would be an alternative solution. Besides, this strategy possesses a potential advantage of screening and maintaining highly virulent LyxyMNPV strains. In the present study, we used pupal tissues of L. xylina to successfully establish four LyxyMNPV permissive cell lines. These new lines represent a great hope for extensive study of LyxyMNPV at the pathologic, cellular, and molecular levels. 


\section{Materials and methods}

\subsection{Primary culture and subculture}

Larvae of L. xylina were collected from the low-elevation mountain area located in central Taiwan (Mingjian Township), and reared with leaves of the Formosa sweet gum (Liquidambar formosana) at $25^{\circ} \mathrm{C}$. The larvae were allowed to go through the pupal stage. The 2-4-day-old pupae were collected and surface-sterilized with a $10 \%$ Clorox solution and $70 \%$ iodine alcohol. The internal tissues (without specific selection) from each pupa were picked with a fine forceps and a pipet, and placed in a $25 \mathrm{~cm}^{2}$ flask with $2 \mathrm{ml}$ TNM-FH medium (Hink and Strauss, 1976) containing $100 \mathrm{IU} / \mathrm{ml}$ penicillin (Gibco), $100 \mathrm{mg} / \mathrm{ml}$ streptomycin (Gibco), $1.25 \mathrm{mg} / \mathrm{ml}$ amphotericin B (Sigma), and 16\% heat-inactivated $\left(56^{\circ} \mathrm{C}\right.$ for $\left.30 \mathrm{~min}\right)$ fetal bovine serum (FBS, Hyclone). The primary cultures of pupal tissues were incubated at $28^{\circ} \mathrm{C}$. The first subculture of the primary cultures was performed after 1 month when the cells reach confluence. When subculturing, $2 \mathrm{ml}$ of suspended cells were transferred to a new $25 \mathrm{~cm}^{2}$ flask containing $4 \mathrm{ml}$ of fresh media plus supplements. Thereafter, $3 / 4-4 / 5$ volume of the medium was replaced at intervals of 14 days followed by 4-7 days intervals. After 25 passages, the cells were adapted to $8 \%$ FBS and were routine subcultured at 5 days intervals. Four cell lines from different primary cultures have been successfully established and are designated NTU-LY-1 to -4 , respectively. The approximate passage numbers of the NTU-LY-1 to -4 cells for the following studies were $55,61,58$, and 63 , respectively.

\subsection{Cell morphological observation}

Microscopical images of cells from individual cell lines were captured with an Olympus IX-71 inverted phase-contrast microscope with a digital camera. Cell sizes were calculated according to a calibrated magnification factor. Average cell dimensions were determined from measurements of 30 cells.

\subsection{Cell growth curves}

Cells in $\log$ phase were seeded into $25 \mathrm{~cm}^{2}$ flasks, about $1 \times 10^{6}$ cells each, and cultured with $8 \%$ FBS supplementation at $28^{\circ} \mathrm{C}$. Cell densities were determined by counting the cell numbers within a microscope reticule of which the area at a certain objective was known. The cell densities in five areas of each flask were determined at $24 \mathrm{~h}$ intervals. Cell population doubling time was calculated using the exponential formula described by Kuchler (1977).

\subsection{Random amplified polymorphic DNA-polymerase chain reaction $(R A P D-P C R)$ analysis}

The extraction of total cell DNA from L. xylina larva and the six cell lines, NTU-LY-1 to -4, IPLB-LD-652Y
(L. dispar cell line, Goodwin et al., 1978), and NTU-PNHH (Perina nuda cell line, Wang et al., 1996) were carried out using a tissue and cell genomic DNA purification kit (GeneMark) according to the protocol provided by the manufacturer. Three $10 \mathrm{mer}$ random primers (OPU-09: 5'CCA CAT CGG T; OPU-10: 5'ACC TCG GCA C and OPO-05: 5'CCC AGT CAC T) and PCR conditions used were modified from $\mathrm{Wu}$ et al. (2002). Each PCR consisted of $50 \mu \mathrm{l}$ mixture containing $1 \times$ reaction buffer (with $2 \mathrm{mM}$ $\mathrm{MgSO}_{4}$ ), $200 \mu \mathrm{M}$ dNTP, $2.5 \mathrm{U}$ HiFi DNA polymerase (Yeastern Biotech), $1 \mu \mathrm{M}$ of primer, and $50 \mathrm{ng}$ cellular DNA templates. The PCR was performed under the following conditions: $2 \mathrm{~min}$ at $94^{\circ} \mathrm{C}$ for the initial denaturation; $1 \mathrm{~min}$ at $94^{\circ} \mathrm{C}, 1 \mathrm{~min}$ at $40^{\circ} \mathrm{C}$, and $2 \mathrm{~min}$ at $72^{\circ} \mathrm{C}$ for the next 40 cycles; and $15 \mathrm{~min}$ at $72^{\circ} \mathrm{C}$ for the final extension. The PCR products were analyzed by electrophoresis in a $2 \%$ agarose gel prestained with ethidium bromide and run at $100 \mathrm{~V}$ for $20 \mathrm{~min}$ in TAE buffer.

\subsection{Isozyme analysis}

Cell samples were prepared and run on gels modified from Wang et al. (1996). Briefly, the confluent cells of the five cell lines, NTU-LY-1 to -4, and IPLB-LD-652Y, were harvested from each individual $25 \mathrm{~cm}^{2}$ flask. The cells were centrifuged at $70 \mathrm{~g}$ for $10 \mathrm{~min}$ at $4{ }^{\circ} \mathrm{C}$, resuspended in $500 \mu \mathrm{l}$ of grinding buffer $(0.125 \mathrm{M}$ Tris- $\mathrm{HCl}, 46 \mathrm{mM}$ citric acid, $10 \%$ sucrose, $1 \%$ Triton $\mathrm{X}-100$, and $0.02 \mathrm{mM}$ bromophenol blue), and lysed by three freeze/ thawing cycles in liquid nitrogen and a $37^{\circ} \mathrm{C}$ water bath. The cell lysate was centrifuged at $8500 \mathrm{~g}$ for $5 \mathrm{~min}$. The supernatant liquid was collected and stored at $-20^{\circ} \mathrm{C}$. For sample separation, $10-20 \mu$ of lysate was loaded into each well of a $10 \%$ polyacrylamide gel, and electrophoresed at a constant current of $20 \mathrm{~mA}$ for $2 \mathrm{~h}$. The gels were tested for the three isozymes, esterase, malate dehydrogenase (MDH), and lactate dehydrogenase (LDH) following the protocol of Harris and Hopkinson (1977).

\subsection{Virus infection}

The following viruses were used to test the viral susceptibility of NTU-LY-1 to -4 cells: AcMNPV (Autographa californica NPV) kindly supplied by Dr. M.J. Fraser of Notre Dame University; PnMNPV ( $P$. nuda NPV) collected from infected NTU-PN-HH cells (Wang et al., 1996); LdMNPVlike virus initially isolated from an infected larva of L. xylina and in vitro propagated in IPLB-LD-652Y cells (Yu et al., 1997); and LyxyMNPV collected from an infected larva of $L$. xylina that was LyxyMNPV-positive for PCR-RFLP method described by Wu and Wang (2005).

These four viruses were used to examine the viral susceptibility of three other cell lines as a positive control for virus infectivity (Sf-9, NTU-PN-HH, and IPLB-LD-652Y). AcMNPV, PnMNPV, and LdMNPV-like virus were obtained from their permissive cell lines, Sf-9, NTU-PNHH, and IPLB-LD-652Y, respectively. Semiconfluent cells 

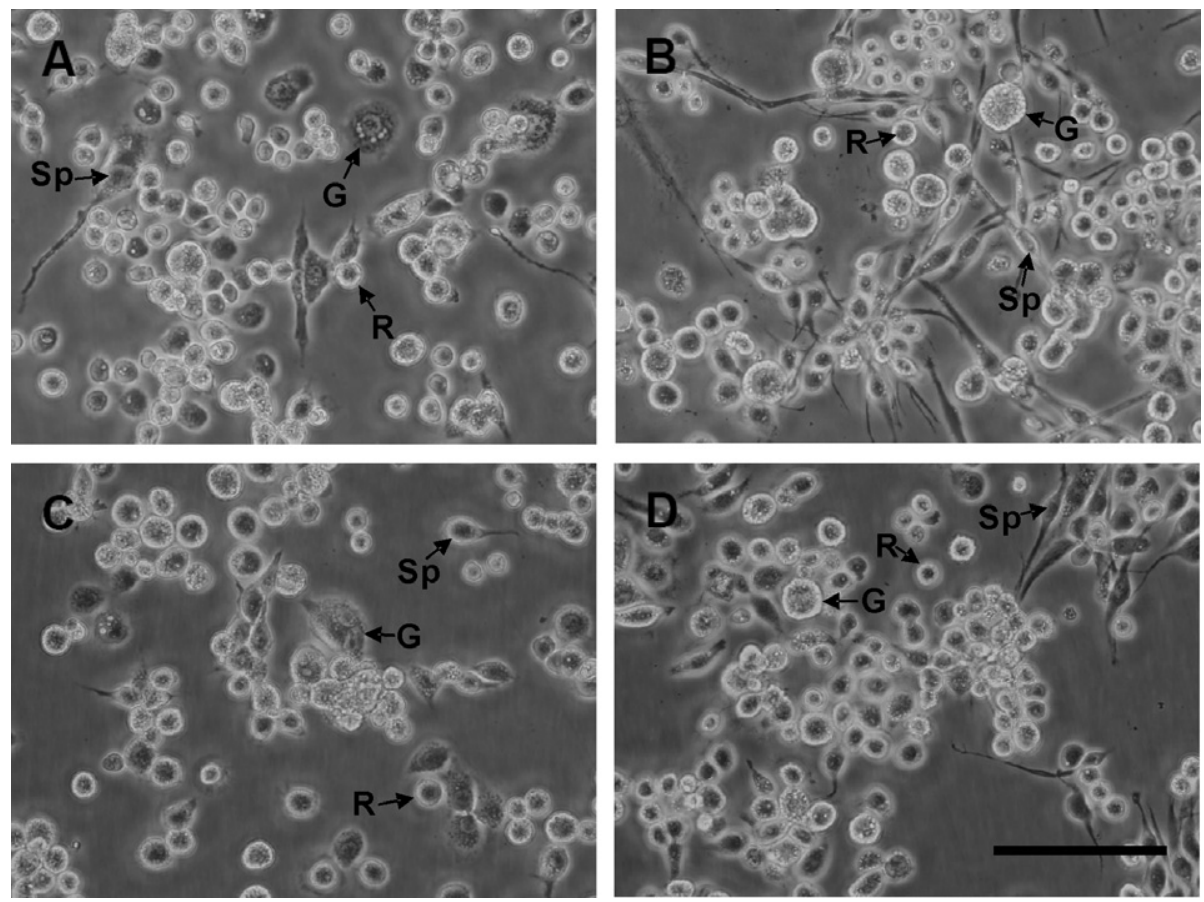

Fig. 1. Phase-contrast micrographs of new L. xylina cell strains, showing: three major cell types in each line, round cells (R), spindle-shaped cells (Sp), and giant cells (G). (A) NTU-LY-1; (B) NTU-LY-2; (C) NTU-LY-3; and (D) NTU-LY-4. All figures are at the same magnification. Bar, $100 \mu \mathrm{m}$.

Table 1

The ratio (and the mean size) of each cell type from the four L. xylina cell lines

\begin{tabular}{lllll}
\hline Cell types & Cell lines & & & \\
\cline { 2 - 5 } & NTU-LY-1 & NTU-LY-2 & NTU-LY-3 & NTU-LY-4 \\
\hline Round cell & $78 \%(16.9 \mu \mathrm{m})$ & $74 \%(16.5 \mu \mathrm{m})$ & $92 \%(16.8 \mu \mathrm{m})$ & $79 \%(16.4 \mu \mathrm{m})$ \\
Spindle-shaped cell & $18 \%(43.5 \mu \mathrm{m}$ in length; & $25 \%(69.5 \mu \mathrm{m}$ in length; & $6 \%(43.0 \mu \mathrm{m}$ in length; & $19 \%(80.7 \mu \mathrm{m}$ in length; \\
& $13.5 \mu \mathrm{m}$ in width $)$ & $12.7 \mu \mathrm{m}$ in width $)$ & $13.8 \mu \mathrm{m}$ in width $)$ & $12.2 \mu \mathrm{m}$ in width) \\
Giant cell & $4 \%(27.3 \mu \mathrm{m})$ & $1 \%(28.1 \mu \mathrm{m})$ & $2 \%(25.0 \mu \mathrm{m})$ & $2 \%(26.3 \mu \mathrm{m})$ \\
\hline
\end{tabular}

(log-phase cells) of NTU-LY-1 to -4 were inoculated with the filtered homogenate of infected $L$. xylina larvae or the filtered culture medium of the NPV-infected cells of Sf-9, NTU-PN-HH, and IPLB-LD-652Y. Both inocula were filtrated through a $0.45 \mu \mathrm{m}$ syringe filter (Sartorius). After $1 \mathrm{~h}$ of adsorption, the viral solution was discarded and the cells were incubated in fresh TNM-FH medium at $28^{\circ} \mathrm{C}$. Occlusion body $(\mathrm{OB})$ containing cells were counted with an inverted phase-contrast Olympus microscope at intervals up to 1 month.

A quantitative study was performed on the four new lines, NTU-LY-1 to -4 with LyxyMNPV since no good cell systems exist for its study or production. Virus replication was assayed by initiating 24-well plates (Nunc) with each cell line, containing $5 \times 10^{4}$ cells per well in $0.5 \mathrm{ml}$ of TNMFH medium supplemented with $8 \%$ FBS. Five wells of each cell line were inoculated with LyxyMNPV at a multiplicity of infection of 5 as determined by the endpoint dilution assay (Summers and Smith, 1988) in the NTU-LY-4 cell line. Plates were sealed with masking tape and maintained at $28^{\circ} \mathrm{C}$ for 10 days. All cells plus the medium were removed from each well by pipeting vigorously, and then centrifuged at $1000 \mathrm{~g}$ for $10 \mathrm{~min}$. The pellet was resuspended in $950 \mu \mathrm{l}$ deionized water, and then $50 \mu \mathrm{l}$ of $10 \%(\mathrm{w} / \mathrm{v})$ sodium laurel sulfate (Sigma) was added. Cells were

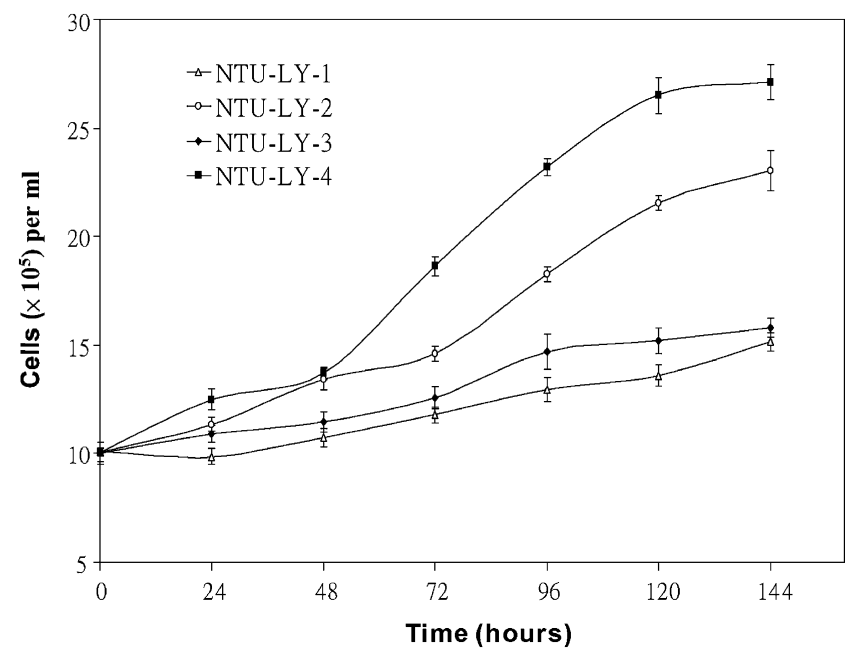

Fig. 2. Growth curves of the four new L. xylina cell lines NTU-LY-1 to -4 . The vertical bars indicate the standard deviation of three independent trials. 


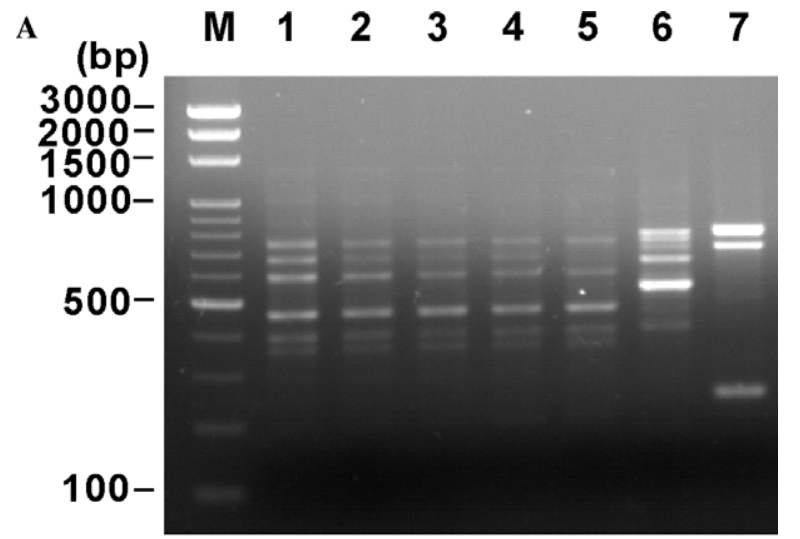

B

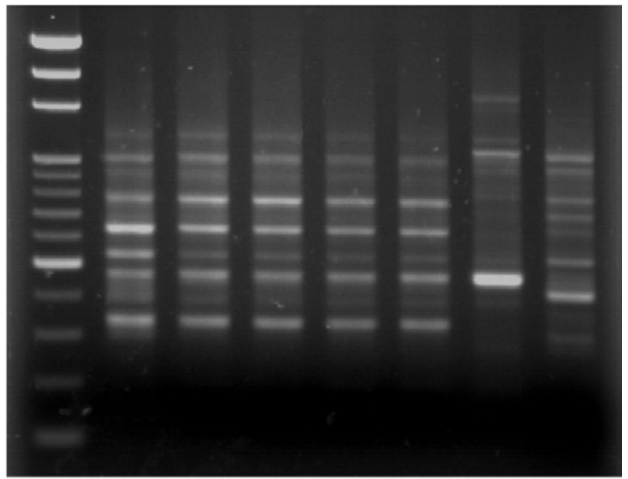

C

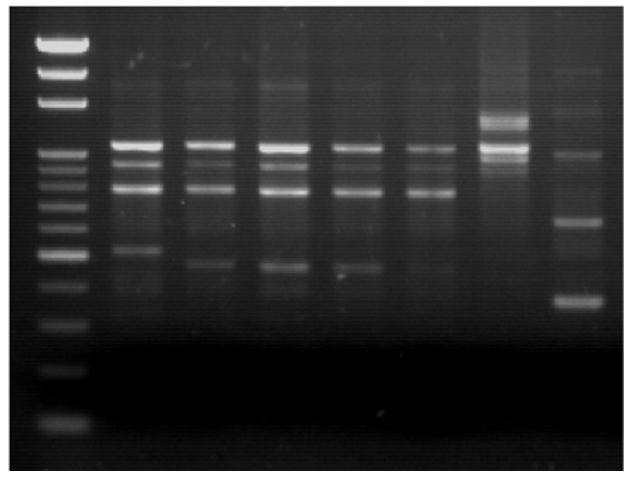

Fig. 3. (A) RAPD profile of a L. xylina larva and the six different cell lines using primer OPU-09. Lane M, Gen-100 DNA Ladder (GeneMark); $1, L$. xylina larva; 2, NTU-LY-1; 3, NTU-LY-2; 4, NTU-LY-3; 5, NTU-LY-4; 6, IPLB-LD-652Y; and 7, NTU-PN-HH. (B and C) Same as (A), but using primers OPU-10 and OPO-05, respectively.

disrupted by vortexing, after which OBs were counted twice in $100 \mu 1$ samples using a hemocytometer. The supernatants were used for budded viral titration. Budded virus yields were determined by the endpoint dilution assay using NTU-LY-4 cells and expressed as TCID $_{50} / \mathrm{ml}(50 \%$ tissue culture infectious dose).

\section{Results and discussion}

\subsection{LY cell morphology}

Four cell lines derived from the pupal tissues of the $L$. xylina were established in vitro and designated NTU-LY-1 to -4 , respectively. All four cell lines have now been cultured for approximately 80 passages during two years. The mor-

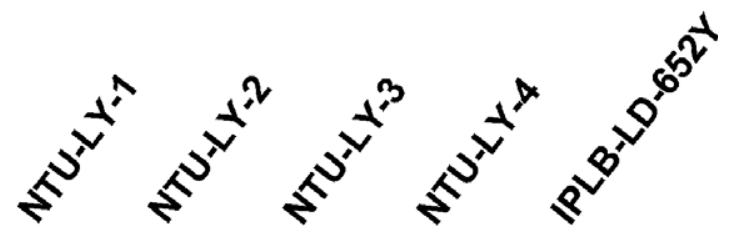

A

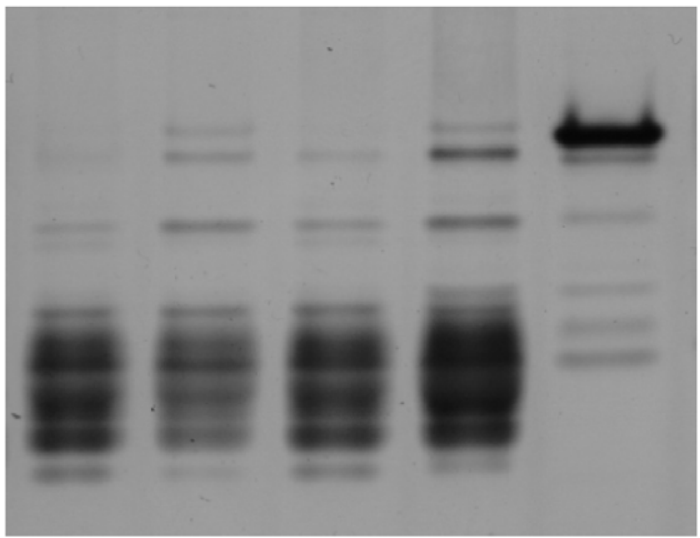

B

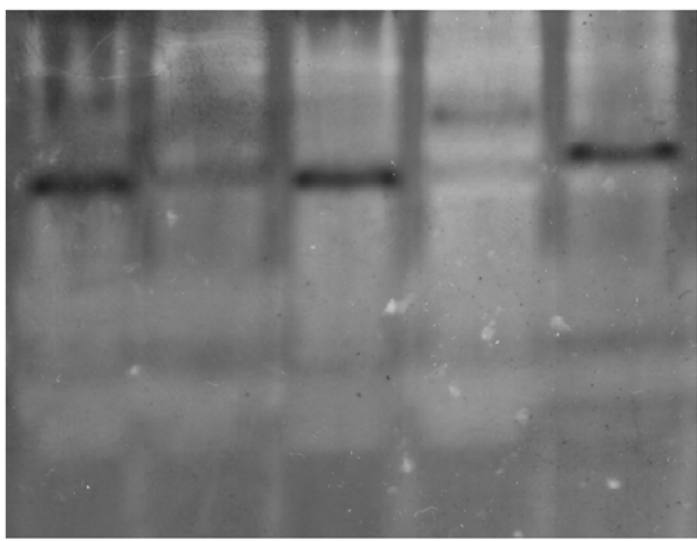

C

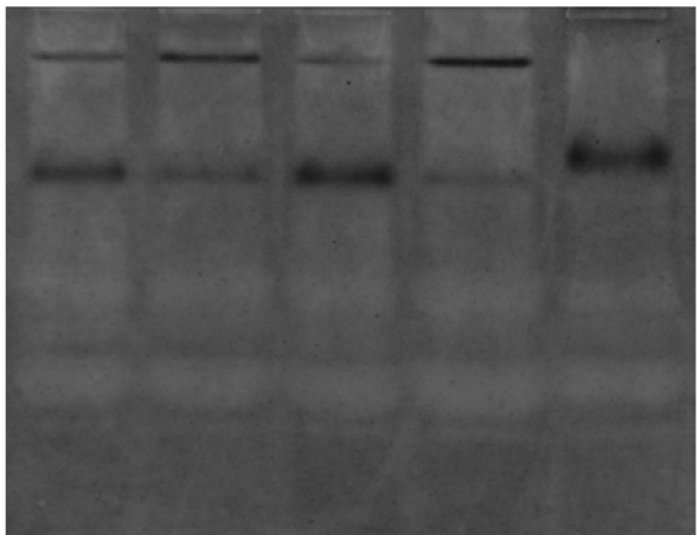

Fig. 4. The isozyme patterns of NTU-LY-1 to -4 cells. (A) Esterase, (B) MDH, and (C) LDH compared with IPLB-LD-652Y cells. The name of each cell line used in this study is indicated at the top of the figures.

phologies of these cell lines are seen in Fig. 1. Each cell line was heterogeneous in nature, consisting primarily of round cells, followed by spindle-shaped and giant cells. Table 1 shows the ratio and the size of each different cell types in the respective cell lines. Slight differences between these four cell lines were observed. For example, NTU-LY-1 was characterized by containing more giant cells than the other 

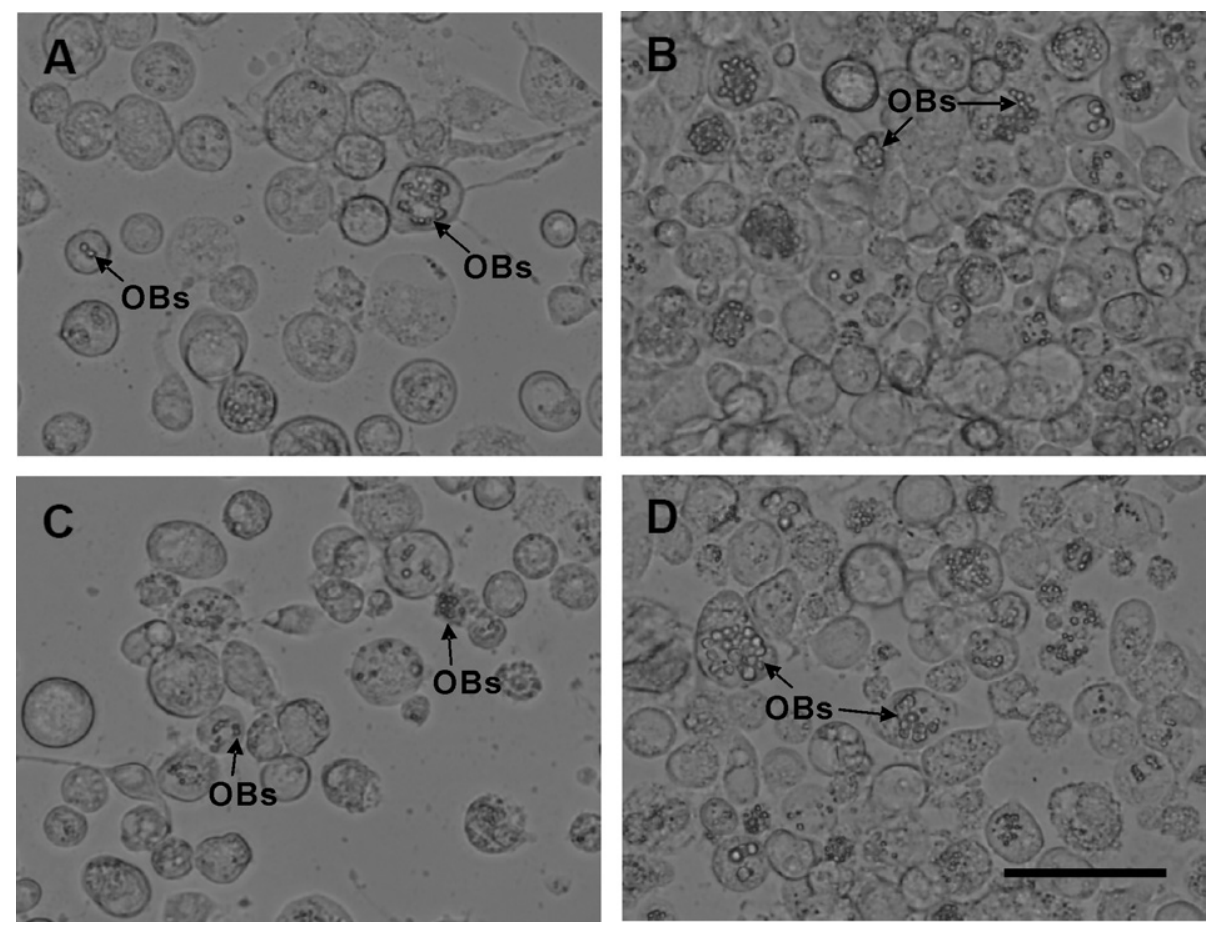

Fig. 5. Cytopathology of the four new L. xylina cell lines NTU-LY-1 to -4 infected with LyxyMNPV showing presence of OBs at $7 \mathrm{~d}$ post-inoculation. All figures are at the same magnification. Bar, $50 \mu \mathrm{m}$.

Table 2

Replication of nucleopolyhedroviruses in the cell lines from L. xylina

\begin{tabular}{|c|c|c|c|c|}
\hline \multirow[t]{2}{*}{ Viruses } & \multicolumn{4}{|l|}{ Cell lines } \\
\hline & NTU-LY-1 & NTU-LY-2 & NTU-LY-3 & NTU-LY-4 \\
\hline LyxyMNPV & ++ & +++ & ++ & +++ \\
\hline LdMNPV-like virus & ++ & +++ & ++ & +++ \\
\hline PenuMNPV & + & ++ & + & +++ \\
\hline AcMNPV & - & - & - & - \\
\hline
\end{tabular}

Note. -, no CPE apparent;,$+ 20-40 \% ;++, 50-80 \% ;+++$, over $80 \%$ of cells with $\mathrm{CPE}(\mathrm{OBs})$.

cell lines. NTU-LY-2 and NTU-LY-4 were both typical of spindle-shaped cells, while NTU-LY-3 was characterized by predominantly round cells $(92 \%)$.

\subsection{Cell growth}

Growth curves that are typical of those generated by the four cell lines are shown in Fig. 2. The NTU-LY-4 cells showed a faster growth rate than the other LY cells. The population doubling times of NTU-LY-1 to -4 were estimated to be $177,74,105$, and $66 \mathrm{~h}$, respectively.

\subsection{Characterization}

The RAPD-PCR analysis showed similar DNA profiles for the four new L. xylina cell lines and the L. xylina larva from which indicated that their genotypes were essentially identical (Fig. 3). In contrast, the DNA profiles mentioned above were quite distinct from those of the two cell lines, IPLB-LD-652Y and NTU-PN-HH. These results indicated that all cells of NTU-LY-1 to -4 are derived from the L. xylina.

The esterase, MDH, and LDH isozyme patterns divided obviously the four new L. xylina cell lines into two groups: NTU-LY-1 and NTU-LY-3 form one group while NTULY-2 and NTU-LY-4 form the other (Fig. 4). Nevertheless, no enzyme patterns of the four L. xylina cell lines were similar to that of IPLB-LD-652Y. In addition, comparing patterns previously obtained with other continuous cell lines maintained in our laboratory (data not shown) showed that the NTU-LY-1 to -4 are unique, verifying they are new cell lines.

\subsection{Viral susceptibility}

All of the new lines were susceptible to the LyxyMNPV. Typical cytopathogenic effects were observed, such as numerous OBs formed in the hypertrophied nucleus of each infected cell (Fig. 5). Furthermore, these cell lines were also susceptible to LdMNPV-like virus and PnMNPV that originally were isolated from other Lymantriidae hosts, and the cells with the LdMNPV-like and PnMNPV infections also produced OBs. In contrast, all four cell lines showed no cytopathology with AcMNPV (Table 2).

The quantitative studies with LyxyMNPV indicated that NTU-LY-1 to -4 produced $7.1 \pm 2.16,29.5 \pm 5.53$, $6.1 \pm 3.21$, and $21.8 \pm 2.59 \quad($ mean $\pm \mathrm{SD}) \times 10^{5} \mathrm{OBs} / \mathrm{ml}$, respectively. These results revealed NTU-LY-2 and NTULY-4 were capable of producing more OBs than the other two cell lines. Although there is no good explanation as to why different cell lines produce variable amounts of virus, 
Lynn and Shapiro (1998) suspected that this phenomenon ultimately relates to the actual cell type represented by the cultured cells since it is clear that different tissues in the insect become infected at different times and produce different quantities of virus. In addition, the endpoint dilution assay indicated that the budded virus titer produced by NTU-LY-1 to -4 were $3.72 \times 10^{7}, 6.31 \times 10^{7}, 2.57 \times 10^{7}$, and $4.32 \times 10^{7} \mathrm{TCID}_{50} / \mathrm{ml}$, respectively. Only slight quantitative differences with that form of the virus the four new cell lines produced. These cell lines may be applicable to studies of insect pathogenic viruses and baculovirus expression vector systems. Further subcloning these cell lines is underway to gain a homogenous line with high susceptibility to the LyxyMNPV for mass production of this virus.

\section{Acknowledgments}

This work was supported by the Grant NSC-94-2313-B002-099 from National Science Council of Taiwan and the Grant 94AS-13.2.1-BQ-B5 from Council of Agriculture, Executive Yuan, Republic of China.

\section{References}

Chang, Y.C., Weng, Y.C., 1985. Morphology, life habit, outbreak and control of casuarina tussock moth (Lymantria xylina Swinhoe). Q. J. Chinese For. 18, 29-36.

Chao, J.T., Schaefer, P.W., Fan, Y.B., Lu, S.S., 1996. Host plants and infestation of casuarina moth Lymantria xylina in Taiwan. Taiwan J. For. Sci. 11, 23-28.

Cheng, S., Xie, Q., Li, Y., Zhu, Z., 1987. Bioassay on the infectivity and field trials of nuclear polyhedrosis virus against Lymantria xylina. Chinese J. Bio. Con. 3, 33-34.

Goodwin, R.H., Tompkins, G.J., McCawley, P., 1978. Gypsy moth cell lines divergent in viral susceptibility. I. Culture and identification. In Vitro (Rockville) 14, 485-493.

Grace, T.D.C., 1962. Establishment of four strains of cells from insect tissues grown in vitro. Nature 195, 788-789.

Granados, R.R., McKenna, K.A., 1995. Insect cell culture methods and their use in virus research. In: Schuler, M.L., Wood, H.A., Granados, R.R., Hammer, D.A. (Eds.), Baculovirus Expression Systems and Biopesticides. Wiley-Liss Press, New York, pp. 13-39.

Harris, H., Hopkinson, D.A., 1977. Handbook of Enzyme Electrophoresis in Human Genetics. North-Holland Press, Amsterdam.
Hink, W.F., Strauss, E., 1976. Growth of the Trichoplusia ni (TN-368) cell line in suspension culture. In: Kurstak, E., Maramorosch, K. (Eds.), Invertebrate Tissue Culture, Applications in Medicine, Biology, and Agriculture. Academic Press, New York, pp. 297-300.

Hink, W.F., Thomsen, D.R., Davidson, D.J., Meyer, A.L., Castellino, F.J., 1991. Expression of three recombinant proteins using baculovirus vectors in 23 insect cell lines. Biotechnol. Prog. 7, 9-14.

Kuchler, R.J., 1977. Development of animal cell populations in vitro. In: Kuchler, R.J. (Ed.), Biochemical Methods in Cell Culture and Virology. Dowden, Hutchingon, and Ross, Inc. Press, Stroudsburg, pp. 90-113.

Liang, D.R., Cai, Y.N., Liu, D.Y., Zang, Q.L., 1986. The Atlas of Insect Viruses of Human. Science Technology Publishing House, Beijing.

Lynn, D.E., 1999. Development of insect cell lines: virus susceptibility and applicability to prawn cell culture. Methods in Cell Science 21, 173181.

Lynn, D.E., Shapiro, M., 1998. New cell lines from Heliothis virescens: characterization and susceptibility to baculoviruses. J. Invertebr. Pathol. 72, 276-280.

Maeda, S., Kwai, T., Obinata, M., Fujiwara, H., Horiuchi, T., Saeki, Y., Furusawa, M., 1985. Production of human interferon in silkworm using a baculovilrus vector. Nature 315, 592-594.

Matsumura, S., 1933. Lymantriidae of Japan-Empire. Ins. Matsum. 7, 111-152.

Smith, G.E., Summers, M.D., Fraser, M.J., 1983. Production of human beta interferon in insect cells infected with a baculovirus expression vector. Mol. Cell. Biol. 3, 2156-2165.

Summers, M.D., Smith, G.E., 1988. A manual of methods for baculovirus vectors and insect cell culture procedure. Texas Agricultural Experiment Station, No. 1555.

Vaughn, J.L., 1981. Insect cells for insect virus production. In: Maramorosch, K. (Ed.), Advances in Cell Culture, vol. 1. Academic Press, New York, pp. 281-295.

Wang, C.H., Chou, C.M., Liu, H.C., Kau, S.L., Kou, G.H., Lo, C.F., 1996. Continuous cell line from pupal ovary of Perina nuda (Lepidoptera: Lymantriidae) that is permissive to nuclear polyhedrosis virus from $P$. nuda. J. Invertebr. Pathol. 67, 199-204.

Wu, C.Y., Wang, C.H., 2005. Characterization and polyhedrin gene cloning of Lymantria xylina multiple nucleopolyhedrovirus. J. Invertebr. Pathol. 88, 238-246.

Wu, J., King, G., Daugulis, A.J., Faulkner, P., Bone, D.H., Goosen, M.F.A., 1989. Engineering aspects of insect cell suspension culture: a review. Microbiol. Biotechnol. 32, 249-255.

Wu, C.Y., Yang, H.N., Lo, C.F., Wang, C.H., 2002. A Perina nuda cell line (NTU-Pn-HF) from pupal ovary that is persistently infected with a picorna-like virus (PnPV). Appl. Entomol. Zool. 37, 171-179.

Xiao, G.R., 1992. Forest Insects of China, Second ed. China Forestry Publishing House, Beijing.

Yu, C.C., Kao, H.H., Chao, J.T., Lu, S.S., Wang, C.H., 1997. The Characterization of Lymantria xylina nucleopolyhedrovirus (LyxyNPV) and the establishment of in vitro multiplication of LyxyMNPV. Chinese J. Entomol. 17, 11-22. 